\title{
molecules
}

ISSN 1420-3049

(C) 2007 by MDPI

www.mdpi.org/molecules

Review

\section{Biological Activities of Hydrazone Derivatives}

\section{Sevim Rollas* and Ş. Güniz Küçükgüzel}

Marmara University, Faculty of Pharmacy, Department of Pharmaceutical Chemistry, 34668, Turkey

* Author to whom correspondence should be addressed E-mail: sevim@sevimrollas.com

Received: 13 March 2007; in revised form: 11 August 2007 / Accepted: 16 August 2007 / Published: 17 August 2007

\begin{abstract}
There has been considerable interest in the development of novel compounds with anticonvulsant, antidepressant, analgesic, antiinflammatory, antiplatelet, antimalarial, antimicrobial, antimycobacterial, antitumoral, vasodilator, antiviral and antischistosomiasis activities. Hydrazones possessing an azometine - $\mathrm{NHN}=\mathrm{C} \underline{\mathrm{H}}-$ proton constitute an important class of compounds for new drug development. Therefore, many researchers have synthesized these compounds as target structures and evaluated their biological activities. These observations have been guiding for the development of new hydrazones that possess varied biological activities.
\end{abstract}

Keywords: Hydrazones, hydrazide-hydrazones, biological activity, isoniazid.

\section{Contents:}

1. Introduction

2. Biological activity 1915

2.1. Anticonvulsant Activity 1915

2.2. Antidepressant Activity 1916

2.3. Analgesic, Antiinflammatory and Antiplatelet Activity 1916

2.4. Antimalarial Activity 1918

2.5. Antimicrobial Activity 1919

2.6. Antimycobacterial Activity 1922 
2.7. Antitumoral Activity

2.8. Vasodilator Activity

2.9. Antiviral Activity

3.0. Schistosomiasis

3. Review articles related with hydrazones

1934

\section{Introduction}

Hydrazones have been demonstrated to possess, among other, antimicrobial, anticonvulsant, analgesic, antiinflammatory, antiplatelet, antitubercular and antitumoral activities. For example, isonicotinoyl hydrazones are antitubercular; 4-hydroxybenzoic acid[(5-nitro-2-furyl)methylene]hydrazide (nifuroxazide) is an intestinal antiseptic; 4-fluorobenzoic acid[(5-nitro-2-furyl)methylene]hydrazide [1] and 2,3,4-pentanetrione-3-[4-[[(5-nitro-2-furyl)methylene]hydrazino]carbonyl]phenyl]hydrazone [2], which were synthesized in our Department, have antibacterial activity against both Staphylococcus aureus ATCC 29213 and Mycobacterium tuberculosis H37Rv at a concentration of $3.13 \mu \mathrm{g} / \mathrm{mL}$. $N^{1}$-(4-Methoxybenzamido)benzoyl]- $N^{2}$-[(5-nitro-2-furyl)methylene]hydrazine, which was also synthesized in our Department [3], demonstrated antibacterial activity. In addition, some of the new hydrazide-hydrazones that we have recently synthesized were active against the same strain of $M$. tuberculosis H37Rv between the concentrations of 0.78-6.25 $\mu \mathrm{g} / \mathrm{mL}$ [4].

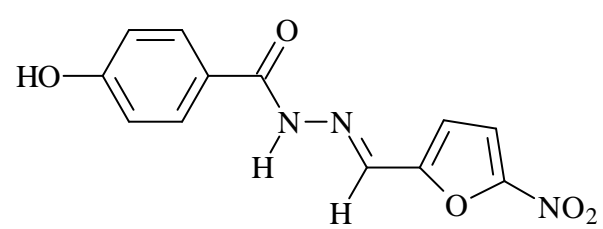

Nifuroxazide

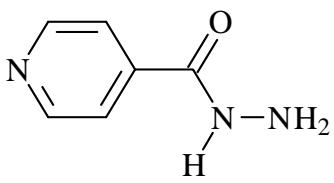

Isoniazid

Isonicotinic acid hydrazide (isoniazid, INH) has very high in vivo inhibitory activity towards $M$. tuberculosis H37Rv. Sah and Peoples synthesized INH hydrazide-hydrazones 1 by reacting INH with various aldehydes and ketones. These compounds were reported to have inhibitory activity in mice infected with various strains of $M$. tuberculosis [5]. They also showed less toxicity in these mice than INH $[5,6]$ Buu-Hoi et al. synthesized some hydrazide-hydrazones that were reported to have lower toxicity than hydrazides because of the blockage of $-\mathrm{NH}_{2}$ group. These findings further support the growing importance of the synthesis of hydrazide-hydrazones compound [7].

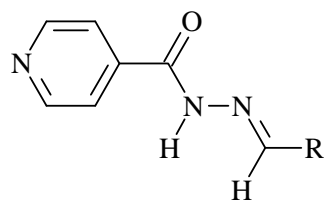

1

Iron is necessary for the biochemical reactions of living organisms. Desferrioxamine is an agent which is used for the treatment of a complication called "Iron Overload Disease". Researchers have synthesized hydrazones of INH by using various aldehydes and their iron complexes and evaluated 
these complexes for their antitumoral activity. The mechanism of antitumoral activity of iron complexes is the inhibition of ribonucleotide reductase, which is an important enzyme for conversion of ribonucleotides to deoxyribonucleotides. Copper complexes of INH that facilitate the intercellular transport of INH were synthesized and evaluated for their antitubercular activity.

Hydrazones containing an azometine $-\mathrm{NHN}=\mathrm{C} \underline{\mathrm{H}}$ - proton are synthesized by heating the appropriate substituted hydrazines/hydrazides with aldehydes and ketones in solvents like ethanol, methanol, tetrahydrofuran, butanol, glacial acetic acid, ethanol-glacial acetic acid. Another synthetic route for the synthesis of hydrazones is the coupling of aryldiazonium salts with active hydrogen compounds. In addition, 4-acetylphenazone isonicotinoylhydrazones was prepared by Amal and Ergenç [8] by exposing an alcohol solution of 4-acetylphenazone and INH to sunlight or by mixing them with a mortar in the absence of the solvent.

Hydrazide-hydrazones compounds are not only intermediates but they are also very effective organic compounds in their own right. When they are used as intermediates, coupling products can be synthesized by using the active hydrogen component of -CONHN=CH- azometine group [9]. $N$-Alkyl hydrazides can be synthesized by reduction of hydrazones with $\mathrm{NaBH}_{4}$ [10], substituted 1,3,4oxadiazolines can be synthesized when hydrazones are heated in the presence of acetic anhydride [1,11,12]. 2-Azetidinones can be synthesized when hydrazones react with trietylamine chloro acetylchloride[13]. 4-Thiazolidinones are synthesized when hydrazones react with thioglycolic acid/ thiolactic acid [3,14] (Scheme 1).

\section{Scheme 1}

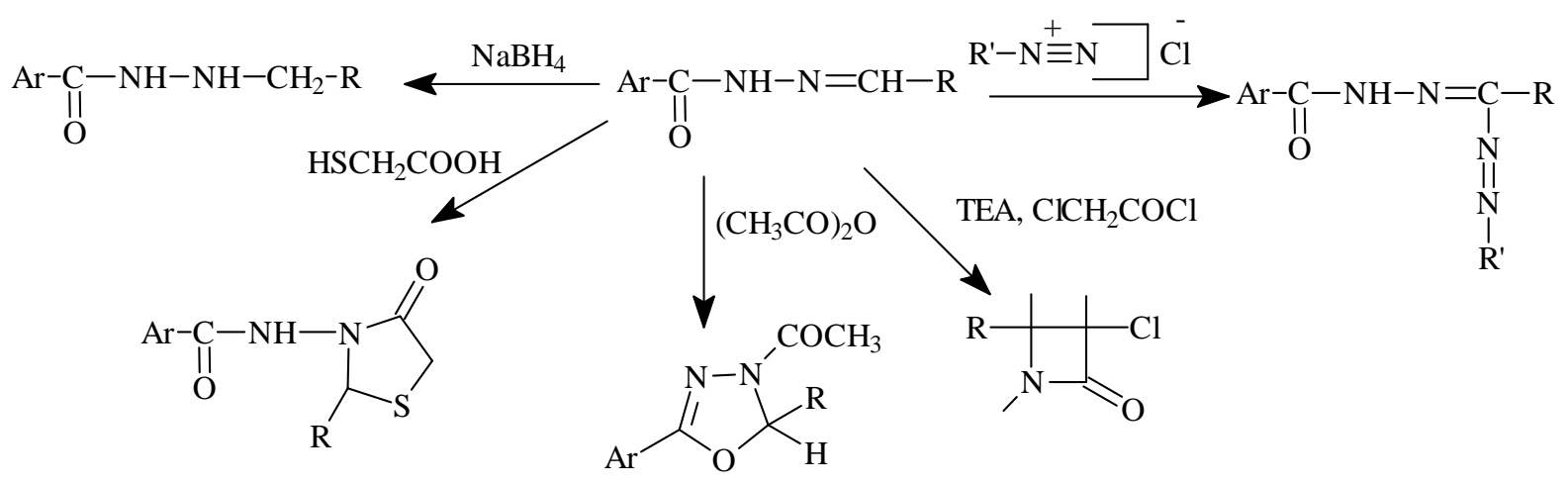

Many effective compounds, such as iproniazide and isocarboxazide, are synthesized by reduction of hydrazide-hydrazones. Iproniazide, like INH, is used in the treatment of tuberculosis. It has also displays an antidepressant effect and patients appear to have a better mood during the treatment. Another clinically effective hydrazide-hydrazones is nifuroxazide, which is used as an intestinal antiseptic.

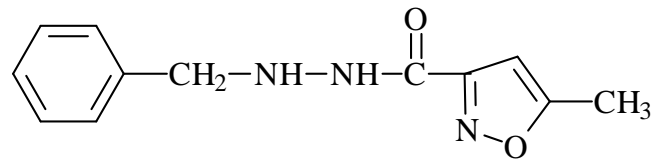

Isocarboxazide<smiles>CC(C)NNC(=O)c1ccncc1</smiles>

Iproniazide 
A number of studies have investigated the in-vitro and in-vivo metabolism of hydrazide-hydrazones. In in-vitro metabolism studies, it has been found that hydrazide-hydrazones undergo hydrolytic reactions and aromatic rings undergo aromatic hydroxylation reactions $[15,16]$ (Scheme 2).

\section{Scheme 2}

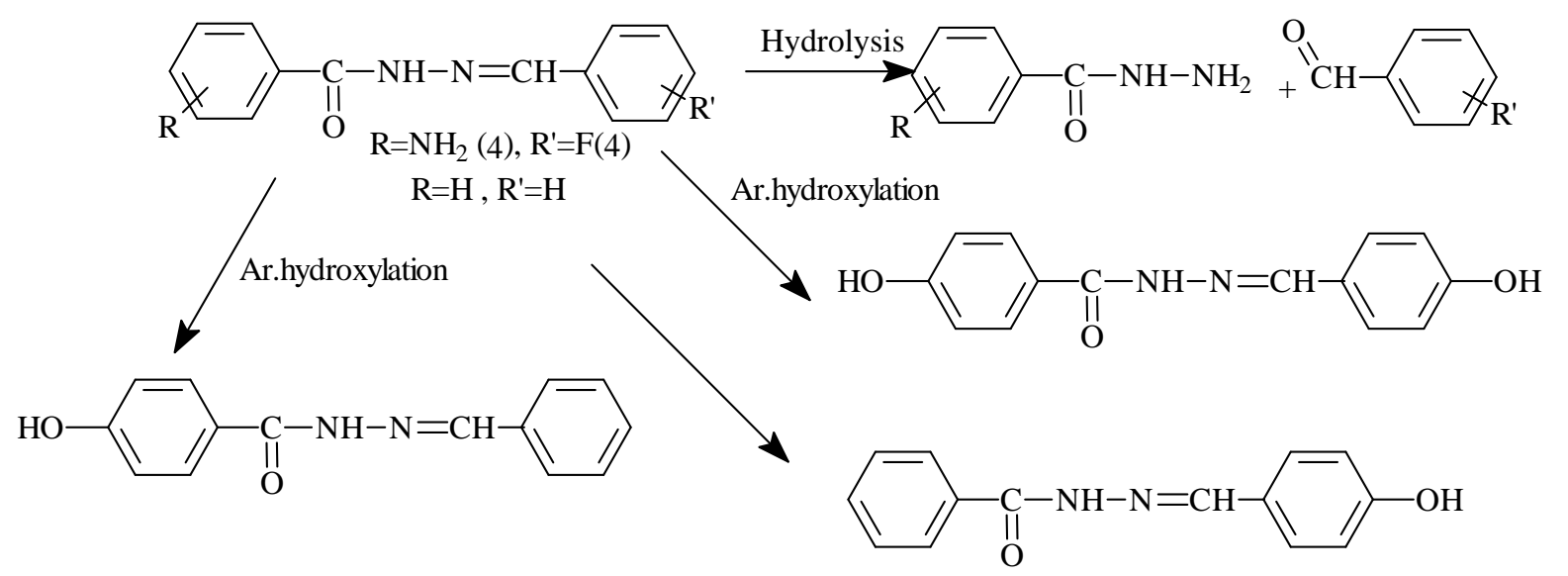

Gülerman et al. investigated the in vivo metabolism of 4-fluorobenzoic acid ((5-nitro-2-furyl)methylene-hydrazide, a hydrazide derivative that is effective against $S$. aureus ATCC 29213. They confirmed the presence of the substrate and 4-fluorobenzoic acid metabolite in blood and blood cells [17] (Scheme 3).

\section{Scheme 3}<smiles>O=C(N/N=C/c1ccc([N+](=O)[O-])o1)c1ccc(F)cc1</smiles><smiles>Cc1cc(F)ccc1C(=O)O</smiles>

Küçükgüzel et al. studied the in vitro hepatic microsomal metabolism of $N$-(4-chlorobenzyl)- $N$ ' benzoylhydrazine (CBBAH). The corresponding hydrazone, namely benzoic acid (4-chlorophenyl)methylenehydrazide was detected as the major in vitro metabolic product [18] (Scheme 4). 


\section{Scheme 4}

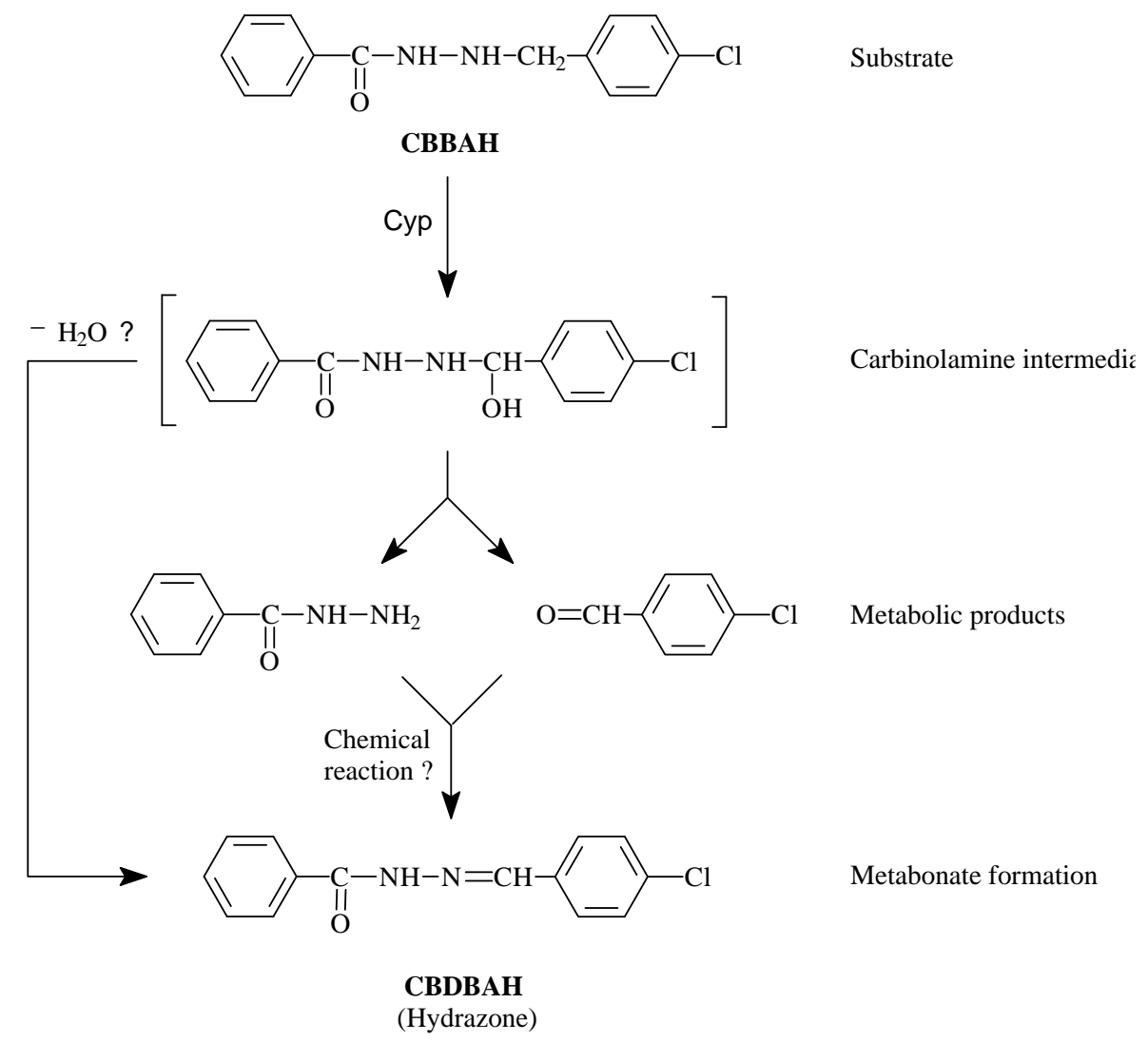

It has been known that the hydrazides (like INH) form $\alpha$-ketoglutaric acid and form hydrazones with vitamin B6 and pyruvic acid. It is clinically important that when tuberculosis patients are treated with INH, reaction of INH with vitamin B6 leads to formation of a hydrazone and development of vitamin B6 deficiency, therefore, patients who are treated with INH should be administered vitamin B6 (Scheme 5).

\section{Scheme 5}

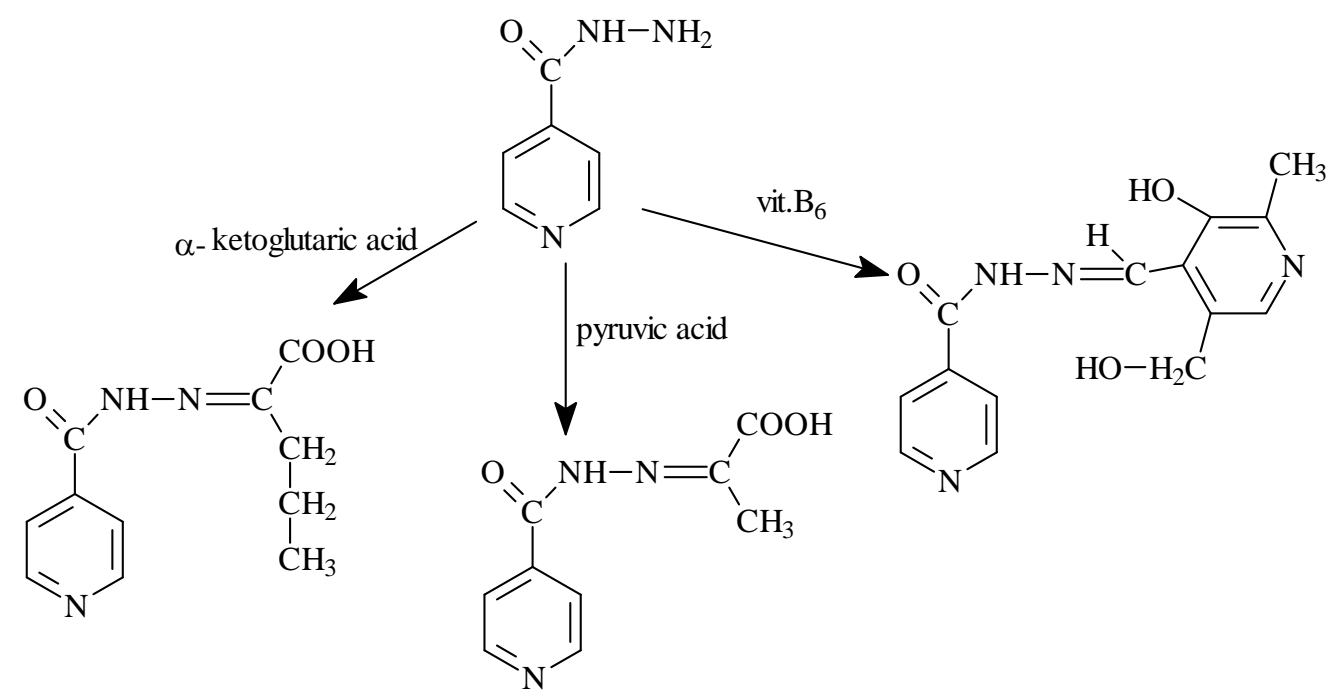


This review critically evaluates the pharmacological activity of the hydrazones that were reported in the past ten years.

\section{Biological activity}

\subsection{Anticonvulsant Activity}

Epilepsy is a common neurological disorder and a collective term given to a group of syndromes that involve spontaneous, intermittent, abnormal electrical activity in the brain. The pharmacotherapy of epilepsy has been archieved during the last decade. Furthermore, although for the last twenty years new antiepileptic drugs have been introduced into clinical practice, the maximal electroshock (MES) test and the subcutaneous pentylenetetrazole (scPTZ) test are the most widely used animal models of epilepsy to characterize the anticonvulsant activity.

The biological results revealed that in general, the acetylhydrazones 2 provided good protection against convulsions while the oxamoylhydrazones 3 were significantly less active. [19].

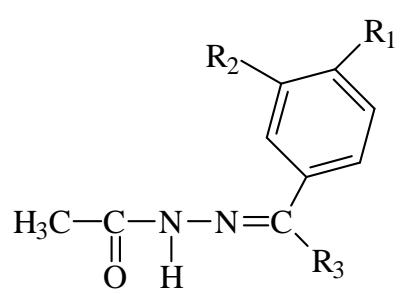

2

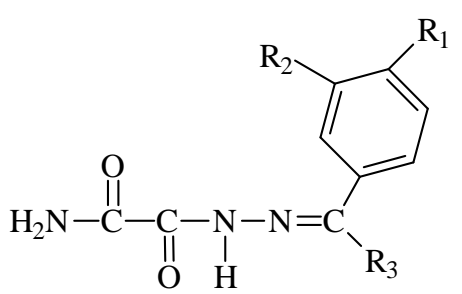

3

Fifteen new hydrazones of (2-oxobenzoxazoline-3-yl)acetohydrazide $\mathbf{4}$ were synthesised and their antiepileptic activity was tested in scPTZ test. The 4-fluoro derivative was found to be more active than the others [20].<smiles>[R]c1ccc(/C=N/NC(=O)Cn2c(=O)oc3ccccc32)cc1</smiles>

4

4-Aminobutyric acid (GABA) is the principal inhibitory neurotransmitter in the mammalian brain. GABA hydrazones 5 were designed and synthesized and evaluated for their anticonvulsant properties in different animal models of epilepsy such as MES, scPTZ, subcutaneous strychine (scSTY) and intraperitonal picrotoxin (ipPIC) induced seizure tests. Some of the compounds were effective in these models [21].

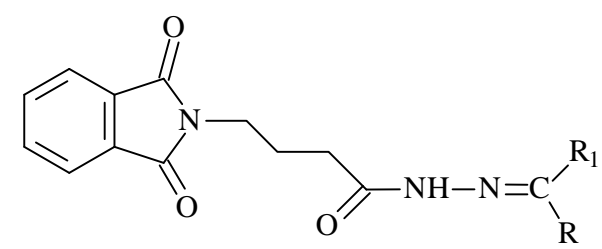




\subsection{Antidepressant Activity}

Iproniazide, isocarboxazide and nialamide, which are hydrazide derivatives, exert their action by inhibiting the enzyme monoamine oxidase (MAO). Inhibition results in increased levels of norepinephrine, dopamine, tyramine and serotonin in brain neurons and in various other tissues. There have been many reports on the antidepresant / MAO-inhibiting the activity of hydrazones derived from substituted hydrazides and reduction products.

Ten new arylidenehydrazides 6 which were synthesized by reacting 3-phenyl-5sulfonamidoindole-2-carboxylic acid hydrazide with various aldehydes, evaluated for their antidepresant activity. 3-Phenyl-5-sulfonamidoindole-2-carboxylic acid 3,4-methylenedioxy / 4methyl / 4-nitrobenzylidene-hydrazide showed antidepresant activity at $100 \mathrm{mg} / \mathrm{kg}$ [10].

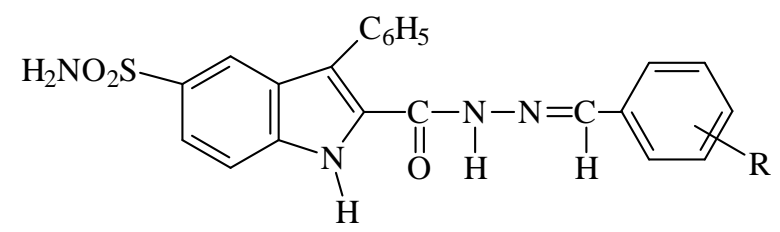

6

\subsection{Analgesic, Antiinflammatory and Antiplatelet Activity}

Non-steroidal anti-inflammatory drugs (NSAIDs) have a wide clinical use for the treatment of inflammatory and painful conditions including rheumatoid arthiritis, soft tissue and oral cavity lesions, respiratory tract infections and fever. The two isoforms of cyclooxygenase (COX) are poorly distinguishable by most of the classical NSAIDs and these agents actually inhibit COX-1 extensively, besides COX-2, leading to gastrointestinal injury, suppression of TXA2 formation and platelet aggregation. The combination of these interactions is probably the reason for gastrointestinal bleeding as the most serious complication of these drugs. Some evidences suggest that the hydrazone moiety present in some compounds possess a pharmacophoric character for the inhibition of COX.

The most important antiinflammatory derivative 2-(2-formylfuryl)pyridylhydrazone 7 presented a $79 \%$ inhibition of pleurisy at a dose of $80.1 \mu \mathrm{mol} / \mathrm{kg}$. The authors also described the results concerning the mechanism of the action of these series of $\mathrm{N}$-heterocyclic derivatives in platelet aggregation that suggests a $\mathrm{Ca}^{2+}$ scavenger mechanism. Compound 7 was able to complex $\mathrm{Ca}^{2+}$ in invitro experiments at $100 \mu \mathrm{M}$ concentration, indicating that these series of compounds can act as $\mathrm{Ca}^{2+}$ scavenger depending on the nature of the aryl moiety present at the imine subunit [22].

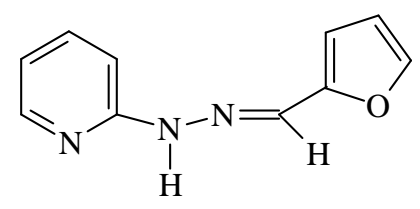

7

A new series of antinociceptive compounds that belong to the $\mathrm{N}$-acylarylhydrazone class were synthesized from natural safrole.[(4'-N,N-Dimethylaminobenzylidene-3-(3',4'-methylenedioxyphenyl) 
propionylhydrazine] $\mathbf{8}$ was more potent than dipyrone and indomethacine, are used as standard antiinflammatory/antinociceptive drugs [23].<smiles>CN(C)c1ccc(/C=N/NC(=O)CCc2ccc3c(c2)OCO3)cc1</smiles>

8

The antiplatelet activity of novel tricyclic acylhydrazone derivatives $\mathbf{9}$ was evaluated by their ability to inhibit platelet aggregation of rabbit platelet-rich plasma induced by platelet-activating factor (PAF) at $50 \mathrm{nM}$. Benzylidene- / 4'-bromobenzylidene 3-hydroxy-8-methyl-6-phenylpyrazolo[3,4b]thieno-[2,3-d]pyridine-2-carbohydrazide were evaluated at $10 \mu \mathrm{M}$, presenting, respectively, 10.4 and 13.6\% of inhibition of the PAF-induced platelet aggregation [24].

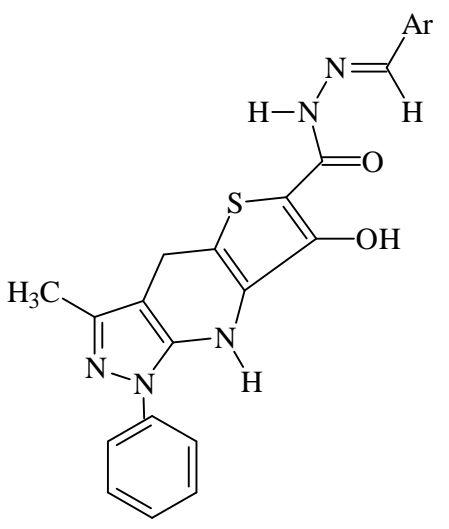

9

The evaluation of platelet antiaggregating profile let to identification of a new potent prototype of antiplatelet derivative, that is benzylidene $10 \mathrm{H}$-phenothiazine-1-carbohydrazide $\left(\mathrm{IC}_{50}=2.3 \mu \mathrm{M}\right) \mathbf{1 0}$, which acts in the arachidonic acid pathway probably by inhibition of platelet COX-1 enzyme. Additionally, the change in para-substituent group of acylhydrazone framework permitted to identify a hydrophilic carboxylate derivative and a hydrophobic bromo derivative as two new analgesics that are more potent than dipyrone, which is the standard, possessing selective peripheral or central mechanism of action [25].<smiles>O=C(N/N=C/[Al])c1cccc2c1Nc1ccccc1S2</smiles> 
Gökhan-Kelekçi et al. synthesized hydrazones containing 5-methyl-2-benzoxazoline. The analgesic effects of 2-[2-(5-methyl-2-benzoxazoline-3-yl)acetyl]-4-chloro- / 4-methyl benzylidene hydrazine 11c and 11d were found to be higher than those of morphine and aspirin. In addition, 2-[2(5-methyl-2-benzoxazoline-3-yl)acetyl]-4- methoxybenzylidene hydrazine $11 e$ at $200 \mathrm{mg} / \mathrm{kg}$ dose possessed the most antiinflammatory activity [26].<smiles>O=C(Cn1c(=O)oc2ccccc21)NN=Cc1ccc(Cl)cc1</smiles>

$11 \mathrm{c}$<smiles>Cc1ccc(/C=N/NC(=O)Cn2c(=O)oc3ccccc32)cc1</smiles>

11d

Duarte et al. have described $N^{\prime}$-(3,5-Di-tert-butyl-4-hydroxybenzylidene)-6-nitro-1,3benzodioxole-5-carbohydrazine 12c as a novel antiinflammatory compound [27].<smiles>CC(C)(C)c1cc(/C=N/NC(=O)c2cc3c(cc2[N+](=O)[O-])OCO3)cc(C(C)(C)C)c1O</smiles>

12c

\subsection{Antimalarial Activity}

Malaria is a disease caused by parasitic protozoa of the genus Plasmodium which afflicts more than 500 million people worldwide and causes approximately 2 million deaths each year. The spread of multidrug-resistant Plasmodium falciparum has highlighted the urgent need to discover new antimalarial drugs.

The aroylhydrazone chelator 2-hydroxy-1-naphthylaldehyde isonicotinoyl hydrazone $\mathbf{1 3}$ showed greater antimalarial agent activity than desferrioxamine against chloroquine-resistant and -sensitive parasites [28].

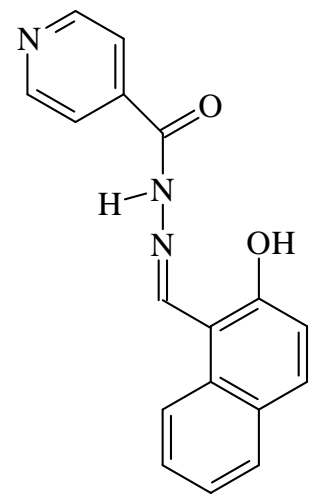


A series of $N^{1}$-arylidene- $N^{2}$-quinolyl- 14 and $N^{2}$-acrydinylhydrazones- 15 were synthesized and tested for their antimalarial properties. The new synthesized compounds, including 14d-g and 15a-c showed an antiplasmodial activity against the chloroquine-sensitive D10 strain in the same range of chloroquine (CQ). Similarly, $\mathbf{1 4 f}$ and $\mathbf{1 4 g}$ displayed the same activity as CQ against chloroquinesensitive 3D-7 strain, while compound $\mathbf{1 5 b}$ was 10 times more potent than CQ. Two analogues $\mathbf{1 5 b}$ and 15c, were more active against W2 CQ-resistant than D10 CQ-sensitive strains [29].<smiles>[R]c1ccc2nccc(NN=C[AlH2])c2c1</smiles>

14d-g<smiles>COc1[X]c2c(NN=[W])c3ccc(Cl)cc3nc2cc1</smiles>

15a-c

1-Substituted phenyl- $N^{\prime}$-[(substitutedphenyl)methylene]-1H-pyrazole-4-carbohydrazides 16 were synthesized and their leishmanicidal and cytotoxic effects were compared to the prototype drugs (ketoconazole, benznidazole, allopurinol and pentamidine) in vitro. The $1 H$-pyrazole-4carbohydrazide derivatives with $\mathrm{X}=\mathrm{Br}, \mathrm{Y}=\mathrm{NO}_{2}$ and $\mathrm{X}=\mathrm{NO}_{2}, \mathrm{Y}=\mathrm{Cl}$ demonstrated the highest activity and they were more effective on promastigotes forms of L.amazonensis than on L. chagasi and L. braziliensis species [30].<smiles>O=C(N/N=C/c1ccc(Cl)cc1)c1cnn(-c2ccc([N+](=O)[O-])cc2)c1</smiles>

16

\subsection{Antimicrobial Activity}

The dramatically rising prevalence of multi-drug resistant microbial infections in the past few decades has become a serious health care problem. The search for new antimicrobial agents will consequently always remain as an important and challenging task for medicinal chemists.

Ethyl 2-arylhydrazono-3-oxobutyrates $\mathbf{1 7}$ were synthesized in order to determine their antimicrobial properties. Compound $\mathbf{1 7 d}$ showed significant activity against $S$. aureus whereas the others had no remarkable activity on this strain. Compound $\mathbf{1 7 e}$ was found to be more active than the others against Mycobacterium fortuitum at a MIC value of $32 \mu \mathrm{g} / \mathrm{ml}$ [31]. 
<smiles>CCOC(=O)/C(=N/Nc1ccc(-c2n[nH]c(=S)n2-c2ccccc2)cc1)C(C)=O</smiles>

17d<smiles>CCOC(=O)/C(=N/Nc1ccc(-c2n[nH]c(=O)n2-c2ccccc2)cc1)C(C)=O</smiles>

$17 \mathbf{e}$

$N^{1}$-(4-methoxybenzamido)benzoyl]- $N^{2}$-[(5-nitro-2-furyl)methylene]hydrazine $\mathbf{1 8}$ inhibited the growth of several bacteria and fungi [3].

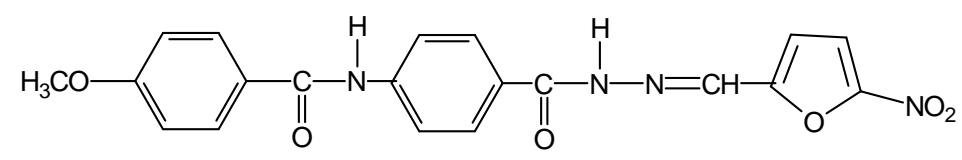

18

Nifuroxazide and six analogs 19 were synthesized by varying the substituent at the $p$-position of the benzene ring and the heteroatom of the heterocyclic ring. These compounds were evaluated for their antimicrobial activity against $S$. aureus ATCC 25923 and found to be active at concentration 0.16-63.00 $\mu \mathrm{g} / \mathrm{mL}$ [32].

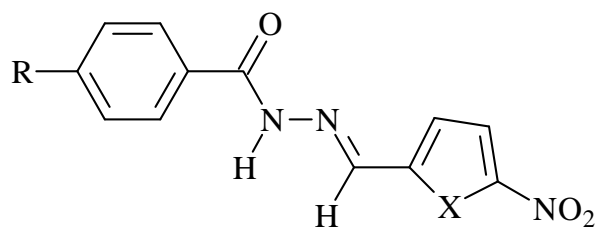

19

$N^{2}$-Substituted alkylidene/arylidene-6-phenylimidazo[2,1-b]thiazole-3-acetic acid hydrazides 20 were synthesized and evaluated for their in vitro antimicrobial activity. Some compounds showed antimicrobial activity against S. aureus ATCC 6538, S. epidermidis ATCC 12228, T .mentagrophytes var.Erinacei NCPF-375, T. rubrum and M. audounii (MIC 25-0.24 $\mu \mathrm{g} / \mathrm{mL}$ ) [33].<smiles>CCCCCCCc1cn2c(CC(=O)N/N=C/C=C/c3ccc([N+](=O)[O-])o3)csc2n1</smiles>

$20 \mathbf{j}$

Turan-Zitouni et al. found 5-bromoimidazo[1,2-a]pyridine-2-carboxylic acid benzylidenehydrazide 21 and 5-bromoimidazo[1,2-a]pyridine-2-carboxylic acid 4-methoxybenzylidenehydrazide 22 to possess antimicrobial activity at $3.9 \mu \mathrm{g} / \mathrm{mL}$ against E. fecalis and S. epidermis [34]. 
<smiles></smiles>

21<smiles></smiles>

22

A series of hydrazones derived from 1,2-benzisothiazole hydrazides $\left(\mathrm{R}_{1}=\mathrm{H}\right) \mathbf{2 3 - 2 7}$ as well as the parent cyclic (23 and 26) and acyclic (24, 25 and 27) 1,2-benzisothiazole hydrazides, were synthesized and evaluated as antibacterial and antifungal agents. All of the 2-amino-1,2-benzisothiazole-3(2H)-one derivatives, belonging to series $\mathbf{2 3}$ and $\mathbf{2 6}$ showed good antibacterial activity against Gram positive bacteria. Most of them were also active against yeasts, too [35].<smiles>[R]c1ccc2sn([R1])c(=O)c2c1</smiles>

$23(\mathrm{R}=\mathrm{H}), 26\left(\mathrm{R}=\mathrm{CH}_{3}\right)$<smiles>[R]NC(=O)c1nsc2ccccc12</smiles>

24<smiles>[R]NC(=O)Cc1nsc2ccc([R])cc12</smiles>

25(R=H), $27\left(\mathrm{R}=\mathrm{CH}_{3}\right)$

Rollas et al. synthesized a series of hydrazide hydrazones 28 and 1,3,4-oxadiazolines of 4-fluorobenzoic acid hydrazide as potential antimicrobial agents and tested these compounds for their antibacterial and antifungal activities against S. aureus, E. coli, P. aeruginosa and C. albicans. From these compounds, 4-fluorobenzoic acid[(5-nitro-2-furyl)methylene] hydrazide (28a) showed equal activity as ceftriaxone against $S$. aureus. In addition, the MIC values of compounds 28c and 28d for the same strain were in the range of those reported for ceftriaxone according to NCCLS 1997 [1].

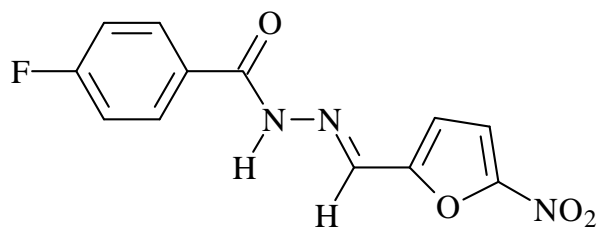

28a

Küçükgüzel et al. synthesized diflunisal hydrazide-hydrazone derivatives. 2',4'-Difluoro-4hydroxybiphenyl-3-carboxylic acid [(5-nitro-2-furyl)methylene] hydrazide (29a) has shown activity against S. epidermis HE-5 and S. aureus HE-9 at $18.75 \mu \mathrm{g} / \mathrm{mL}$ and $37.5 \mu \mathrm{g} / \mathrm{mL}$, respectively. 2',4'Difluoro-4-hydroxybiphenyl-3-carboxylic acid [(2,4,6-trimethylphenyl)methylene] hydrazide (29e) has exhibited activity against Acinetobacter calcoaceticus IO-16 at a concentration of $37.5 \mu \mathrm{g} / \mathrm{mL}$, whereas Cefepime, the drug used as standard, has been found to be less active against the same microorganisms [36]. 
<smiles>[R]/C=N/NC(=O)c1cc(-c2ccc(F)cc2F)ccc1O</smiles>

A series of hydrazones synthesized from various cholesterol derivatives $\mathbf{3 0}$ were evaluated for their in vitro antimicrobial properties against human pathogens. The activity was highly dependent on the structure of the different compounds involved. The best results have been obtained with tosylhydrazone cholesterol derivatives exhibiting activities against C. albicans (CIP 1663-80) at a concentration of $1.5 \mu \mathrm{g} / \mathrm{mL}$ [37].

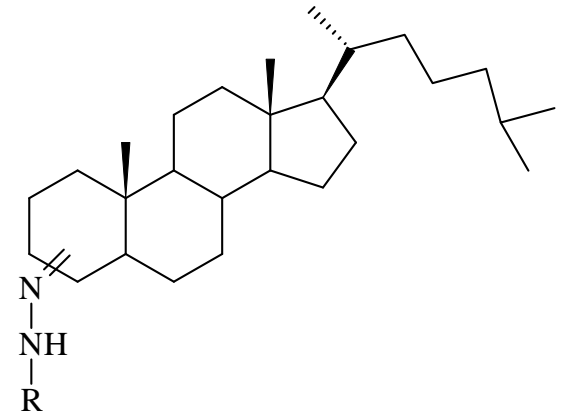

4-Substituted benzoic acid [(5-nitro-thiophene-2-yl)methylene]hydrazides 31 were synthesized as potential bacteriostatic activity and some of them indeed showed bactericidal activity [38].<smiles>[R]c1ccc(C(=O)N/N=C/c2ccc([N+](=O)[O-])s2)cc1[R]</smiles>

31

\subsection{Antimycobacterial Activity}

Tuberculosis is a serious health problem that causes the death of some three million people every year worldwide [39]. In addition to this, the increase in $M$. tuberculosis strains resistant to front-line antimycobacterial drugs such as rifampin and INH has further complicated the problem, which clearly indicates the need for more effective drugs for the efficient management of tuberculosis. Meyer and Mally prepared new hydrazones by reacting isoniazid (INH) with benzaldehyde, o-chlorobenzaldehyde and vanilin [5]. Shchukina et al. prepared INH hydrazide-hydrazones $\mathbf{1}$ by reacting INH with various 
aldehydes and ketones; the compounds were reported to have activity in mice which had been infected with various strains of $M$. tuberculosis, and also indicated lower toxicity than INH $[5,6]$.

The reaction of 1-methyl-1H-2-imidazo[4,5-b]pyridinecarboxylic acid hydrazide with substituted aldehydes yielded the corresponding hydrazide-hydrazones. Compound 32 exhibited antimycobacterial activity against M.tuberculosis H37 Rv, M. tuberculosis 192, M. tuberculosis 210, isolated from patients and resistant against INH, ethambutol, rifampicine at $31.2 \mu \mathrm{g} / \mathrm{mL}[40]$.

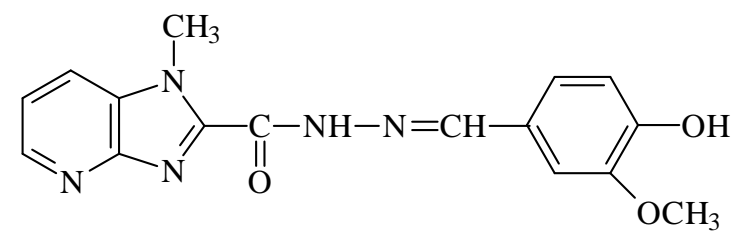

32

Various different 2,3,4-pentanetrione-3-[4-[[(5-nitro-2-furyl/pyridyl/substituted-phenyl)methylene]hydrazino]carbonyl]phenyl]hydrazones 33 were synthesized. All the synthesized compounds were evaluated for their antimycobacterial activity against $M$. fortuitum ATCC 6841 and M. tuberculosis H37Rv. Of the compounds screened, 33e and 33g were found to be active against $M$. fortuitum at an MIC value of $32 \mu \mathrm{g} / \mathrm{mL}$. Compound 33a, which exhibited $>90 \%$ inhibition in the primary screen at $12.5 \mu \mathrm{g} / \mathrm{mL}$ against $M$. tuberculosis H37Rv, was the most promising derivative for antituberculosis activity. Results obtained from the level II screening showed that the actual MIC and IC $_{50}$ values of 32a were 3.13 and $0.32 \mu \mathrm{g} / \mathrm{mL}$, respectively. The same compound was also tested against Mycobacterium avium, which was observed not to be susceptible to 33a [2].<smiles>CC(=O)C(=NNc1ccc(C(=O)N/N=C/c2ccc([N+](=O)[O-])o2)cc1)C(C)=O</smiles>

33a

Isonicotinoylhydrazones have been further reacted with pyridinecarboxaldehydes to give the corresponding pyridylmethyleneamino derivatives 34. The new synthesized hydrazones and their pyridylmethyleneamino derivatives were tested for their activity against mycobacteria, Gram-positive and Gram-negative bacteria. The cytotoxicity was also tested. Several compounds showed a good activity against $M$. tuberculosis $\mathrm{H} 37 \mathrm{Rv}$ and some isonicotinoylhydrazones showed a moderate activity against a clinically isolated $M$. tuberculosis (6.25-50 $\mu \mathrm{g} / \mathrm{mL})$ which was INH resistant [41].

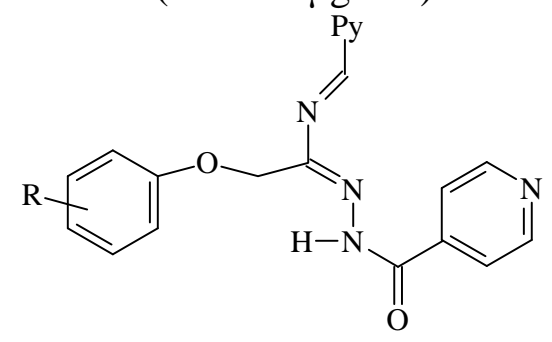


The reaction of 2-acetylimidazo[4,5-b]pyridine with INH yielded the corresponding hydrazidehydrazones 35. This compound exhibited activity against $M$. tuberculosis H37 Rv, M. tuberculosis 192, M. tuberculosis 210, isolated from patients and resistant against INH, ethambutol, rifampicine at $3.13 \mu \mathrm{g} / \mathrm{mL}[42]$.<smiles>C/C(=N\NC(=O)c1ccncc1)c1nc2cccnc2[nH]1</smiles>

35

$N^{2}$-Substitutedalkylidene/arylidene-6-phenylimidazo[2,1-b]thiazole-3-acetic acid hydrazides 20 were synthesized and evaluated for in vitro antimycobacterial activity. The compounds exhibited different degrees of inhibition (17-98 \%) against M. tuberculosis H37 Rv [33].

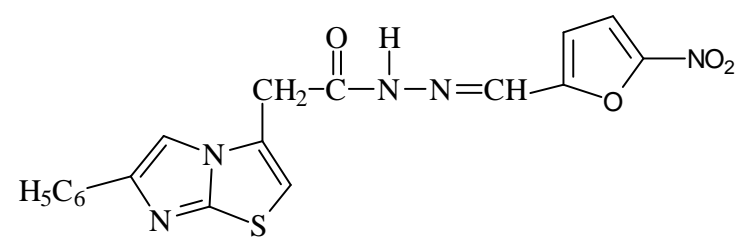

$20 \mathbf{i}$

[5-(Pyridine-2-yl)-1,3,4-thiadiazole-2-yl]thio]acetic acid arylidene-hydrazide derivatives 36 were synthesized and tested for their in vitro antimycobacterial activity. Some compounds showed activity at $20 \mu \mathrm{g} / \mathrm{mL}$ against $M$. tuberculosis and at $40 \mu \mathrm{g} / \mathrm{mL}$ against $M$. avium [43].<smiles>[R]c1ccc(/C=N/NC(=O)CSc2nnc(-c3ccccn3)s2)cc1</smiles>

36

N-Alkylidene/arylidene-5-(2-furyl)-4-ethyl-1,2,4-triazole-3-mercaptoacetic acid hydrazides 37 were synthesized and evaluated for in vitro antimycobacterial activity. The compounds exhibited different degrees of inhibition (3-61\%) against M. tuberculosis H37 Rv at $6.25 \mu \mathrm{g} / \mathrm{mL}$ [44].<smiles>[R]C=NNC(=O)CSc1nnc(-c2ccco2)n1CC</smiles>

37

A series of 4-quinolylhydrazones 38 were synthesized and tested against M. tuberculosis H37Rv. Preparation of the title compounds was achieved by reaction of 4-quinolylhydrazine and aryl- or heteroarylcarboxaldehydes. Most of the derivates had antitubercular properties; two compounds were identified with the highest activity and they were tested also against M. avium [45]. 
<smiles></smiles>

38

Benzoic acid [(5-nitro-thiophene-2-yl)methylene] hydrazide series 39 were synthesized and tested against M. tuberculosis H37Rv. Rando and co-workwers have applied Topliss methodolgy to a set of nitrogen analogues. 4-Methoxybenzoic acid[(5-nitrothiophene-2-yl)methylene] hydrazide (39a) was demonstrated as being the most active, with a MIC value of $2.0 \mu \mathrm{g} / \mathrm{mL}$ [46].<smiles>COc1ccc(C(=O)N/N=C/c2ccc([N+](=O)[O-])s2)cc1</smiles>

$39 a$

Both hydrazone products, ethyl 2-[(3,5-dimethylpyrazole-4-yl)hydrazono]-3-oxobutyrate 40d and methyl 2-[(3,5-dimethylpyrazole-4-yl)hydrazono]-4-methoxy-3-oxobutyrate 40e showed 29 and 28\% inhibition against M. tuberculosis H37Rv, respectively [47].<smiles>CCOC(=O)/C(=N/Nc1c(C)n[nH]c1C)C(C)=O</smiles>

40d<smiles>CCOC(=O)/C(=N/Nc1c(C)n[nH]c1C)C(=O)COC</smiles>

40e

Novel coupling products $\mathbf{4 1}$ were synthesized and evaluated for their antimycobacterial activity against M. tuberculosis $\mathrm{H} 37 \mathrm{Rv}$ and $M$. avium. Compound $\mathbf{4 1 b}$ was found to be the most potent derivatives of these series with the MIC value of $6.25 \mu \mathrm{g} / \mathrm{mL}$ against $M$. tuberculosis H37Rv [48].<smiles>CC(=O)/C(=N/Nc1ccc(C(=O)N/N=C/c2ccc([N+](=O)[O-])o2)cc1)C(=O)c1ccccc1</smiles> 
[5-(Pyridine-2-yl)-1,3,4-thidiazole-2-yl]acetic acid (3,4-diaryl-3H-thiazole-2-ylidene)hydrazide derivatives 42 were synthesized and tested for their in vitro antimycobacterial activity towards three strains. Compound 42s was exhibited at $20 \mu \mathrm{g} / \mathrm{mL}$ against M.tuberculosis 190, isolated from bronchial aspirates [49].<smiles>Cc1ccccc1-n1c(-c2ccccc2)cs/c1=N/NC(=O)CSc1nnc(-c2ccccn2)s1</smiles>

42s

$N^{\prime}$-\{1-[2-hydroxy-3-(piperazine-1-yl-methyl)phenyl]ethylidene $\}$ isonicotinohydrazide $\mathbf{4 3}$ was found to be the most active compound with the MIC of $0.56 \mu \mathrm{M}$, and it was more potent than INH (MIC of $2.04 \mu \mathrm{M})$. After 10 days of treatment, same compound decreased the bacterial load in murine lung tissue by 3.7-log10 as compared to controls, which was equipotent to INH [50].<smiles>[R]Cc1cccc(/C(C)=N/NC(=O)c2ccncc2)c1O</smiles>

43

As a part of an ongoing search for the new isoniazid-related isonicotinoylhydrazones (ISNEs), 2'monosubstituted isonicotinohydrazides and cyanoboranes 44-48 were studied and evaluated in vitro advanced antimycobacterial screening. Some of tested compounds displayed excellent (MICs ranging from 0.025 to $0.2 \mu \mathrm{g} / \mathrm{mL}$ ) to moderate (6.25 to $12.5 \mu \mathrm{g} / \mathrm{mL}$ ) MICs against ethambutol- and rifampinresistant strains [51].<smiles>[R]C([R])=NNC(=O)c1ccncc1</smiles>

\section{4-48}

Novel fluoroquinolones $\mathbf{4 9}$ containing a hydrazone structure were synthesized and evaluated in vivo against M. tuberculosis H37Rv in Swiss albino mice by Shindikar et al. Results of the study indicate the potent antitubercular activity of the test compouds [52]. 
<smiles>C/C(CN1C(C)CN(c2c(F)c(N)c3c(=O)c(C(=O)O)cn(C4CC4)c3c2F)CC1C)=N\NC(=O)c1ccncc1</smiles>

49

$N^{\prime}$-Arylidene- $N$-[2-oxo-2-(4-aryl-piperazin-1-yl)ethyl]hydrazide derivatives $\mathbf{5 0}$ containing INH hydrazide-hydrazones were synthesized and evaluated antimycobacterial activity against $M$. tuberculosis H37Rv ATCC 27294 and M. tuberculosis clinical isolates. Compound 50h showed in vitro activity against $M$. tuberculosis H37Rv ATCC 27294 (at $1 \mu \mathrm{g} / \mathrm{mL}$ ) and clinical isolates (sensitive and resistant at $0.25-0.5,2-4 \mu \mathrm{g} / \mathrm{mL}$, respectively) [53].<smiles>[R]N1CCN(C(=O)CN(/N=C/c2ccccc2)C(=O)c2ccncc2)CC1</smiles>

50

Sriram et al. synthesized a new series of antimycobacterial agents 51 containing INH hydrazidehydrazones. 1-(4-Fluorophenyl)-3-(4-\{1-[pyridine-4-carbonyl)hydrazono]ethyl $\}$ phenyl)thiourea 51d was found to be most potent compound, with MIC of $0.49 \mu \mathrm{M}$ against M. tuberculosis $\mathrm{H} 37 \mathrm{Rv}$ and INH-resistant M. tuberculosis [54].<smiles>C/C(=N\NC(=O)c1ccncc1)c1ccc(NC(=S)Nc2ccc(F)cc2)cc1</smiles>

51d

In 2006 Nayyar et al. found that the most active compounds of type 52, $N$-(2-fluorophenyl)- $N^{\prime}$ quinoline-2-yl-methylenehydrazine, $N$-(2-adamantan-1-yl)- $N^{\prime}$-quinoline-4-yl-methylene)- $\mathrm{N}^{\prime}$-4-fluorophenyl)hydrazine and $N$-(2-cyclohexyl)- $N^{\prime}$-quinoline-4-yl-methylene)-(2-fluorophenyl)hydrazine exhibited 99\% inhibition at the lowest tested concentration of $3.125 \mu \mathrm{g} / \mathrm{mL}$ against drug-sensitive $M$. tuberculosis H37 strain [55]. 
<smiles>[R]NN=Cc1ccc2ccccc2n1</smiles><smiles>[R]N/N=C\c1cc(C2CCCCC2)nc2ccccc12</smiles><smiles>[R]N/N=C\c1cc(C23CC4CC(CC(C4)C2)C3)nc2ccccc12</smiles>

52

Various diclofenac acid hydrazones 53 were synthesized and evaluated for their antimycobacterial activities against $M$. tuberculosis in vitro and in vivo. Preliminary results indicated that most of the compounds demonstrated better in vitro antimycobacterial activity at concentrations ranging from 0.0383 to $7.53 \mu \mathrm{M}[56]$.

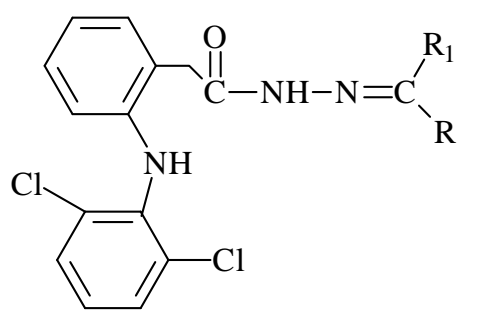

53

Hydrazide-hydrazones 54, based on series of 4-substituted benzoic acid were synthesized and screened for antituberculosis activity. 4-Fluorobenzoic [(5-nitrothiophene-2-yl)methylene]hydrazide 54a showed the highest inhibition (99\%) at a constant concentration level (6.25 $\mu \mathrm{g} / \mathrm{mL})$ [4].

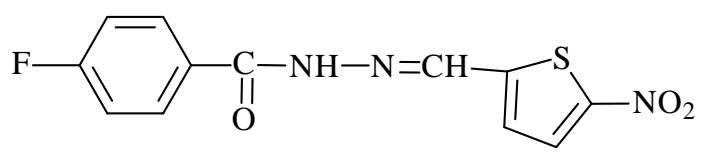

$54 a$

Sixteen new hydrazones $\mathbf{5 5}$ containing a pyrrole ring were synthesized as potential tuberculostatics and nine showed $92-100 \%$ inhibition of $M$. tuberculosis $\mathrm{H} 37 \mathrm{Rv}$ at $6.25 \mu \mathrm{g} / \mathrm{mL}$. Two leads exhibited low minimum inhibitory concentrations (MIC) and excellent selectivity indexes (SI) [57].<smiles>[R]C([R])=NNC(=O)c1ccncc1</smiles><smiles>[R]C([R])=NNC(=O)C(C)n1c(CCCl)cc(C(=O)O)c1C</smiles>

55

$N$-[3-(\{2-[(2E)-2-Benzylidenehydrazino]-2-oxoethyl\}sulfanyl)-5-(-(\{2[(acetyl)amino]-1,3-thiazol4-yl\}methyl)-4H-1,2,4-triazol-4-yl]-3-nitrobenzamide $\quad \mathbf{5 6 f} \quad$ and $\quad N$-[3-(\{2-[(2E)-2-benzylidenehydrazino]-2-oxoethyl $\}$ sulfanyl)-5-(-(\{2[(benzoyl)amino]-1,3-thiazol-4-yl\}methyl)-4H-1,2,4-triazol-4yl]-3-nitrobenzamide $\mathbf{5 6 g}$ have been proven to be most active, with MIC values ranging from 0.39 to $0.78 \mu \mathrm{M}[58]$. 
<smiles>CONc1nc(Cc2nnc(SCC(=O)N/N=C/c3ccccc3)n2NC(=O)c2cccc([N+](=O)[O-])c2)cs1</smiles>

$56 f$<smiles>CC(=O)Nc1nc(Cc2nnc(SCC(=O)N/N=C/c3ccccc3)n2NC(=O)c2cccc([N+](=O)[O-])c2)cs1</smiles>

$56 \mathrm{~g}$

A series of hydrazones 57 were synthesized from INH, pyrazineamide, $p$-aminosalicylic acid (PAS), ethambutol and ciprofloxacin. 2-Hydroxy-4-\{[(isonicotinoylhydrazono)methyl]amino\}benzoic acid 57d showed the highest inhibition (96\%) of M. tuberculosis H37Rv at $0.39 \mu \mathrm{g} / \mathrm{mL}$ [59].<smiles>O=C(N/N=C/Nc1ccc(C(=O)O)c(O)c1)c1ccncc1</smiles>

57d

\subsection{Antitumoral Activity}

A variety of antitumoral drugs are currently in clinical use. The search for antitumoral drugs led to the discovery of several hydrazones having antitumoral activity. Some of diphenolic hydrazones showed maximum uterotrophic inhibition of 70\%, whereas compound 58 exhibited cytotoxicity in the range of 50-70\% against MCF-7 and ZR-75-1 human malignant breast cell lines [60].<smiles>O=[N+]([O-])c1ccc(N/N=C(\Cc2ccccc2)c2ccc(O)cc2)c([N+](=O)[O-])c1</smiles>

58

$N^{\prime}$-(1-\{1-[4-nitrophenyl-3-phenyl-1H-pyrazole-4-yl\}methylene)-2-chlorobenzohydrazide $\mathbf{5 9}$ was found to be the most active, with full panel median growth inhibition, total growth concentration and median lethal concentration mean graph mid-point of 3.79, 12.5 and $51.5 \mu \mathrm{M}$, respectively [61].

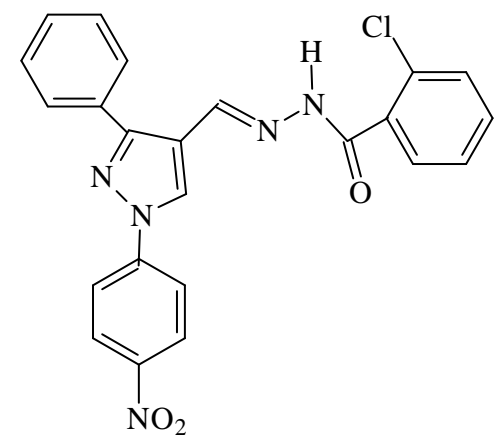


Some novel 2,6-dimethyl-N'-substituted-phenylmethyleneimidazo[2,1-b][1,3,4]thiadiazole-5carbohydrazides 60 were synthesized. (2,6-Dimethyl- $N^{\prime}$-(2-hydroxyphenylmethylidene)imidazo[2,1b] $[1,3,4]$ thiadiazole-5-carbohydrazide 60c showed the most favorable cytotoxicity. In the in vitro screening of National Cancer Institute's 60 human tumor cell lines, this compound demonstrated the most marked effects on the ovarian cancer cell line (OVCAR $\log _{10} \mathrm{GI}_{50}$ value -5.51) [62].<smiles>Cc1nn2c(C(=O)N/N=C/c3ccccc3O)c(C)nc2s1</smiles>

3-[[(6-Chloro-3-phenyl-4(3H)-quinazolinone-2-yl)mercaptoacetyl]hydrazono]-5-fluoro-1H-2indolinone 610 showed the most favourable cytotoxicity against the renal cancer cell line UO-31 $\left(\log _{10} \mathrm{GI}_{50}\right.$ value -6.68) [63].<smiles>O=C(CSc1nc2ccc(Cl)cc2c(=O)n1-c1ccccc1)N/N=C1\C(=O)Nc2ccc(F)cc21</smiles>

\section{0}

Some recently synthesized compounds were found to possess antiproliferative properties. The most active compound of the series was the 3- and 5-methylthiophene-2-carboxaldehyde $\alpha-(N)$ heterocyclichydrazones derivatives 62, which exhibited tumor growth inhibition activity against all cell lines at $\mathrm{GI}_{50}$ values between 1.63 and $26.5 \mu \mathrm{M}$ [64].<smiles>Cc1ccsc1/C=N/NC1=NCC1</smiles><smiles>Cc1ccc(/C=N/NC2=NCC2)s1</smiles>

62

5-Chloro-3-methylindole-2-carboxylic acid(4-nitrobenzylidene)hydrazide 63a was found to arrest T47D cells in $G_{2} /$ Mphase of the cell cycle and to induce apoptosis as measured by the flow cytometry analysis. A 20-fold increase of apoptotic activity was achieved from the screening hit to 5-methyl-3phenylindole-2-carboxylic acid(4-methylbenzylidene) hydrazide 64a and 5-chloro-3-phenylindole-2carboxylic acid(4-nitrobenzylidene)hydrazide $\mathbf{6 4 b}$, with $\mathrm{EC}_{50}$ values of $0.1 \mu \mathrm{M}$ in the caspase activation assay in T47D breast cancer cells. Compound 64b also was found to be highly active in a standard growth inhibition assay with a $\mathrm{GI}_{50}$ value of $0.9 \mu \mathrm{M}$ in T47D cells. Compound 63a and its 
analogs were found to inhibit tubulin polymerization, which is the most probable primary mechanism of the action of these compounds [65].

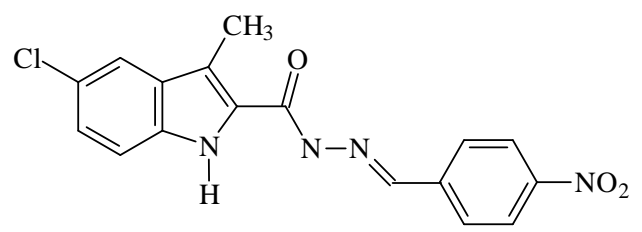

63a

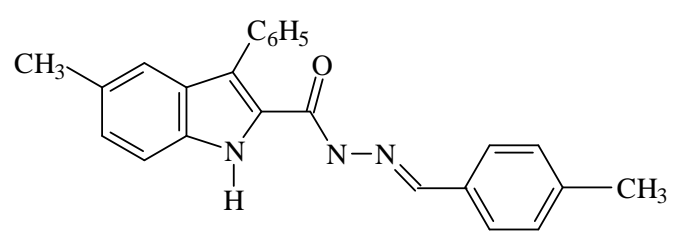

64a

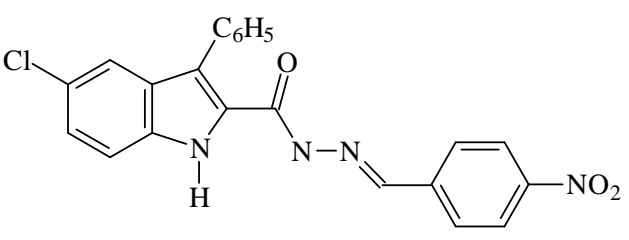

64b

Demirbaş et al. synthesized the new hydrazide-hydrazones containing 65 5-oxo-[1,2,4]triazole ring. Some of these compounds had inhibitory effect on mycelial growth whereas Compounds 65c and 65f were found to possess antitumor activity in breast cancer. [66].<smiles>CCCc1nn(CC(=O)N/N=C/c2ccccc2)c(=O)n1N</smiles>

65c

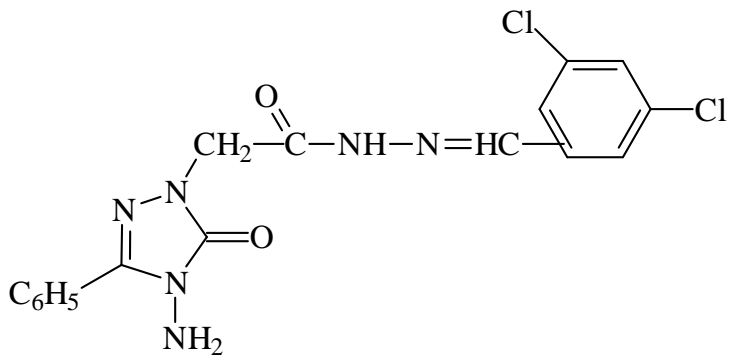

$65 f$

Hydrazinopyrimidine derivatives $\mathbf{6 6}$ were evaluated for their in vitro antitumoral activity in nine different types of human cancers. Some of the newly prepared compounds demonstrated inhibitory effects on the growth of a wide range of cancer cell lines generally at $10^{-5} \mathrm{M}$ to $10^{-7} \mathrm{M}$ concentrations [67].<smiles>[R]C([R])=NNc1nc(N)nc([X])c1C#N</smiles>

66

Several benzo $[d]$ isothiazole hydrazones have been tested for antitumoral activity. Compound $\mathbf{6 7 h}$, bearing a hydroxy group at $o$-position of the benzylidene moiety, was the most potent, with the IC50 against the various cell lines ranging between 0.5 and $8.0 \mu \mathrm{M}$, thus acting equally potent as 6mercaptopurine against the haematological tumors [68]. 
<smiles>O=C(N/N=C/c1ccccc1O)c1nsc2ccccc12</smiles>

$67 \mathrm{~h}$

$N^{\prime}$-Substituted-benzylidene-3,4,5-trimethoxybenzohydrazide $\mathbf{6 8}$ were synthesized and evaluated for their antitumoral activity against some cancer cells. Many hydrazone compounds containing the active moiety (-CONH-N=CH-) showed good antitumor activity. Compounds 68a-c and 68f were highly effective against PC3 cells and 68a, 68c and $\mathbf{6 8 f}$ showed moderate activities against Bcap37 and BGC823 cells [69].<smiles>[R]c1ccc(/C=N/NC(=O)c2cc(OC)c(OC)c(OC)c2)cc1</smiles>

68

6-Amino-4-aryl-2-oxo-1-(1-pyrid-3-yl- or $\quad 4$-yl-ethylidene-amino)-1,2-dihydropyridine-3,5dicarbo-nitrile series 69 exhibited a high percentage of tumor growth inhibition at concentrations of $10^{-5}$ to $10^{-7} \mathrm{M}$ in all cancer cell lines [70].<smiles>[R]c1ccc(-c2c(C#N)c(N)n(/N=C(\C)c3cccnc3)c(=O)c2C#N)cc1</smiles>

69

Duarte et al. described N'-(3,5-Di-tert-butyl-4-hydroxybenzylidene)-6-nitro-1,3-benzodioxole-5carbohydrazine 12c as a novel antiproliferative compound. They observed that 12c was able to inhibit T-cell proliferation (66 \% at $10 \mu \mathrm{M})$ [27].

A series of arylidenehydrazides $\mathbf{7 0}$ were synthesized and evaluated in the National Cancer Institue's against the full panel of 60 human tumour cell lines. Compound 70c demonstrated the most effect on prostate cancer cell line [71].<smiles>O=C(Cc1csc2nc(-c3ccc(Br)cc3)cn12)N/N=C/c1ccc(O)cc1</smiles> 


\subsection{Vasodilator Activity}

Conventional therapy to treat hypertension often involves arterial vasodilation. It is important to find new vasodilators with a potential for clinical use.

A new bioactive compound of the $N$-acylhydrazone class, 3,4-methylenedioxybenzoyl-2-thienyl hydrazone 71, named LASSBio-294, was shown to have inotropic and vasodilatory effects. New derivatives of LASSBio-294 were designed and tested on the contractile responses of rat vascular smooth muscle in vitro. Phenylephrine-induced contractions of aorta was inhibited by the derivatives $\mathrm{N}$-methyl-2-thienylidene-3,4-methylenedioxy-benzoyl hydrazine, named LASSBio-785 and $\mathrm{N}$-allyl-2thienylidene-3,4-methylenedioxy-benzoyl hydrazine, named LASSBio-788. The concentrations necessary to cause $50 \%$ reduction in maximum contractions (IC50) were $10.2+/-0.5$ and $67.9+/-6.5$ $\mu \mathrm{M}$. Vasodilation induced by both derivatives is likely to be mediated by a direct effect on smooth muscle because it was not dependent on the integrity of vascular endothelium. LASSBio-785 was seven times more potent than the reference compound LASSBio-294 (IC50 = 74 $\mu \mathrm{M})$ in producing an endothelium-independent vasodilator effect [72].

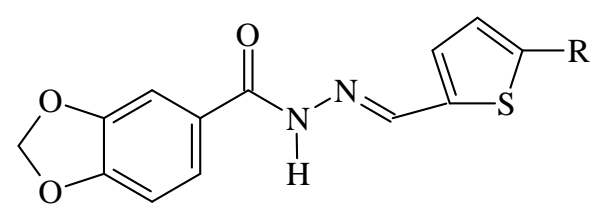

71

\subsection{Antiviral Activity}

HIV infection and AIDS represent one of the first diseases for which the discovery of drugs was performed entirely via a rational drug design approach. Current treatment regimens are based on the use of two or more drugs that belong to group of inhibitors termed as highly active antiretroviral therapy (HAART). Some thiourea compounds were reported to be non-nucleoside inhibitors (NNIs) of the reverse transcriptase (RT) enzyme of the human immunodeficiency virus (HIV). Such hydrazones have been reported to be the potent inhibitors of ribonucleotide reductase activity.

$\mathrm{N}$-Arylaminoacetylhydrazones and $\mathrm{O}$-acetylated derivatives of sugar $\mathrm{N}$-arylaminoacetyl hydrazones were synthesized and evaluated for their antiviral activity against Herpes simplex virus-1 (HSV-1) and hepatitis-A virus (HAV). Some compounds revealed the highest antiviral activity against HAV-27 and HSV-1 [73].

\subsection{Schistosomiasis}

Schistosomiasis or bilharzia is a parasitic disease caused by several species of flatform. Currently, schistosomiasis affects roughly 200 million people in tropical countries, and in certain African communities the process of overcoming schistosomiasis is an important rite of passage. Schistosomiasis causes debilitating nutritional, hematologic and cognitive deficits, with substantial morbidity and mortality in populations. There are five species of flatworms that cause schistosomiasis. Schistosoma mansoni, S. intercalatum, S. haematobium, S. japonicum and S. mekongi. Schistosoma mansoni and S. intercalatum, S. japonicum and S. mekongi cause intestinal and Asian intestinal 
schistosomiasis, respectively. S. haematobium resides in the venous plexus, which causes urinary schistosomiasis [74].

9-Acridanone hydrazones have been developed by Hoffmann-La Roche (Basel-Switzerland). One of these compounds (RO 15-5458/000) was administered at two dose levels $25 \mathrm{mg}$ and $15 \mathrm{mg} / \mathrm{kg}$ body-weight to $S$. mansoni infected vervet-monkeys [75]. In addition, same compounds were found to be effective against $S$. mansoni in mice, killing almost all the skin schistosomules, when administered at the dose of $100 \mathrm{mg} / \mathrm{kg}$. In experiments carried out with Cebus monkeys, the compound RO 15-5458 / 000 was shown to be fully effective at $25 \mathrm{mg} / \mathrm{kg}$ [76].

\section{Review articles related with hydrazones}

There critical reviews have been published recently, and they may give an outlook on the latest research developments on antimycobacterial substances [77-79].

\section{References and Notes}

1. Rollas, S.; Gülerman, N.; Erdeniz, H. Synthesis and antimicrobial activity of some new hydrazones of 4-fluorobenzoic acid hydrazide and 3-acetyl-2,5-disubstituted-1,3,4-oxadiazolines. Farmaco 2002, 57, 171-174.

2. Küçükgüzel, Ş.G.; Rollas, S.; Küçükgüzel, İ; Kiraz, M. Synthesis and Antimycobacterial activity of some coupling products from 4-aminobenzoic acid hydrazones. Eur. J. Med. Chem. 1999, 34, 1093-1100.

3. Küçükgüzel, Ş.G.; Oruç E.E.; Rollas S.; Şahin, F.; Özbek, A. Synthesis, Characterization and biological activity of novel 4-thiazolidinones, 1,3,4-oxadiazoles and some related compounds. Eur. J. Med. Chem. 2002, 37, 197-206.

4. Kaymakçığlu K.B.; Oruç, E.E.; Unsalan, S.; Kandemirli, F.; Shvets, N.; Rollas, S.; Anatholy, D. Synthesis and characterization of novel hydrazide-hydrazones and the study of their structureantituberculosis activity. Eur. J. Med. Chem, 2006, 41, 1253-1261.

5. Sah, P.P.T.; Peoples, S.A. Isonicotinyl hydrazones as antitubercular agents and derivatives for idendification of aldehydes and ketones. J. Am. Pharm. Assoc. 1954, 43, 513-524.

6. Bavin E.M.; Drain, D.J.; Seiler, M.; Seymour, D.E. Some further studies on tuberculostatic compounds. J. Pharm. Pharmacol. 1954, 4, 844-855.

7. Buu-Hoi, P.H.; Xuong, D.; Nam, H.; Binon, F.; Royer, R. Tuberculostatic hydrazides and their derivatives . J. Chem. Soc. 1953, 1358-1364.

8. Amâl, H.; Ergenç, N. Some isonicoticoyl-hydrazones. İ.Ü. Fen Fakültesi Mecmuası. 1957, 22, 390-392.

9. Singh, V.; Srivastava, V.K.; Palit, G.; Shanker, K.; Coumarin congeners as antidepressants. Arzneim-Forsch. Drug. Res. 1992, 42, 993-996.

10. Ergenç, N.; Günay, N.S. Synthesis and antidepressant evaluation of new 3-phenyl-5sulfonamidoindole derivatives, Eur. J. Med. Chem. 1998, 33, 143-148. 
11. Durgun B.B.; Çapan G.; Ergenç, N.; Rollas, S. Synthesis, characterisation and biological evaluation of new benylidenebenzohydrazides and 2,5-disubstituted-2,3-dihydro-1,3,4oxadiazoles. Pharmazie 1993, 48, 942-943.

12. Doğan H.N.; Duran, A.; Rollas, S. ; Şener, G. ; Armutak, Y.; Keyer-Uysal, M. Synthesis and structure elucidation of some new hydrazones and oxadiazolines : anticonlsant activitites of 2-(3acetyloxy-2-naphtyl)-4-acetyl-5-substituted-1,3,4-oxadiazolines. Med. Sci. Res. 1998, 26, 755758.

13. Kalsi, R.; Shrimali, M.; Bhalla, T.N. ; Barthwal, J.P. Synthesis and anti-inflammatory activity of indolyl azetidinones. Indian J. Pharm. Sci. 2006, 41, 353-359.

14. Küçükgüzel, Ş.G. ; Kocatepe A. ; De Clercq, E. ; Şahin F., Güllüce, M. Synthesis and biological activity of 4-thiazolidinones, thiosemicarbazides derived from diflunisal hydrazide. Eur. J. Med. Chem. 2006, 41, 353-359.

15. Kömürcü, Ş.G.; Rollas S.; Ülgen M.; Gorrod J.W; Çevikbaş A. Evaluation of Some Arylhydrazones of p-Aminobenzoic acid hydrazide as Antimicrobial Agents and Their in-vitro Hepatic Microsomal Metabolism. Boll. Chim. Farm. 1995, 134, 375-379.

16. Ülgen M.; Durgun, B.B.; Rollas, S.; Gorrod, J.W. The in vitro hepatic microsomal metabolism of benzoic acid benzylidenehydrazide.Drug Metab. Interact. 1997, 13, 285-294.

17. Gülerman N.N., Oruç, E.E.; Kartal, F.; Rollas, S. In vivo metabolism of 4-fluorobenzoic acid [(5nitro-2-furanyl)methylene] hydrazide in rats. Eur. J .Drug Metab. Pharmacokinet. 2000, 25, 103108.

18. Küçükgüzel, Ş.G.; Küçükgüzel, İ.; Ülgen M. Metabolic and Chemical Studies on N-(4chlorobenzyl)-N'-benzoylhydrazine, Farmaco 2000, 55, 624-630.

19. Dimmock, J.R.; Vashishtha, S.C.; Stables, J.P. Anticonvulsant properties of various acetylhydrazones, oxamoylhydrazones and semicarbazones derived from aromatic and unsaturated carbonyl compounds. Eur. J. Med. Chem. 2000, 35, 241-248.

20. Çakır, B.; Dağ, Ö.; Yıldırım, E.; Erol, K.; Şahin, M.F. Synthesis and anticonvulsant activity of some hydrazones of 2-[(3H)-oxobenzoxazolin-3-yl-aceto]hydrazide. J. Fac. Pharm. Gazi. 2001, 18, 99-106 .

21. Ragavendran, J.; Sriram, D.; Patel, S.; Reddy, I.; Bharathwajan, N. ; Stables, J.; Yogeeswari ,P. Design and synthesis of anticonvulsants from a combined phthalimide-GABA-anilide and hydrazone pharmacophore. Eur. J. Med. Chem. 2007, 42, 146-151.

22. Todeschini, A.R.; Miranda, A.L.; Silva C.M.; Parrini, S.C.; Barreiro, E.J. Synthesis and evaluation of analgesic, antiinflammatory and antiplatelet properties of new 2pyridylarylhydrazone derivatives. Eur. J. Med. Chem. 1998, 33 , 189-199.

23. Lima, P.C., Lima, L.M.; Silva, K.C.; Leda, P.H.; Miranda, A.L.P.; Fraga, C.A.M; Barreiro, E.J.; Synthesis and analgesic activity of novel $\mathrm{N}$-acylhydrazones and isosters, derived from natural safrole. Eur. J. Med. Chem. 2000, 35, 187-203.

24. Fraga, A.G.M.; Rodrigues, C.R.; Miranda, A.L.P.; Barreiro, E.J.; Fraga, C.A.M. Synthesis and pharmacological evaluation of novel heterocyclic acylhydrazone derivatives, designed as PAF antagonists. Eur. J. Pharm. Sci. 2000, 11 , 285-290. 
25. Silva, G.A.; Costa, L.M.M.; Brito, F.C.F.; Miranda, A.L.P.; Barreiro, E.J.; Fraga, C.A.M. New class of potent antinociceptive and antiplatelet $10 \mathrm{H}$-phenothiazine-1-acylhydrazone derivatives. Bioorg. Med. Chem, 2004, 12, 3149-3158.

26. Salgın-Gökşen, U.; Gökhan-Kelekçi, N.; Göktaş, Ö.; Köysal, Y.; Kılıç, E.; Işık, Ş.; Aktay, G.; Özalp, M. 1-Acylthiosemicarbazides, 1,2,4-triazole-5(4H)-thiones, 1,3,4-thiadiazoles and hydrazones containing 5-methyl-2-benzoxazolinones: Synthesis, analgesic-anti-inflammatory and antimicrobial activities. Bioorg. Med. Chem. 2007, 15, 5738-5751.

27. Duarte, C.D.; Tributino, J.L.M.; Lacerda, D.I.; Martins, M.V.; Alexandre-Moreira, M.S.; Dutra, F.; Bechara, E.J.H.; De-Paula, F.S.; Goulart, M.O.F.; Ferreira, J.; Calixto, J.B.; Nunes, M.P.; Bertho, A.L.; Miranda, A.L.P.; Barreiro, E.J.; Fraga, C.A.M.; Synthesis, pharmacological evaluation and electrochemical studies of novel 6-nitro-3,4-methylenedioxyphenyl- $N$ acylhydrazone derivatives : Discovery of LASSBio-881, a new ligand of cannabinoid receptors. Bioorg. Med. Chem. 2007, 15, 2421-2433.

28. Walcourt, A.; Loyevsky, M.; Lovejoy, D.B.; Gordeuk, V.R.; Richardson, D.R. Novel aroylhydrazone and thiosemicarbazone iron chelators with anti-malarial activity against chloroquine-resistant and -sensitive parasites. Int. J. Biochem. Cell Biol. 2004, 36 , 401-407.

29. Gemma, S.; Kukreja, G.; Fattorusso, C.; Persico, M.; Romano, M.; Altarelli, M.; Savini, L.; Campiani, G.; Fattorusso, E.; Basilico, N. Synthesis of N1-arylidene-N2-quinolyl- and N2acrydinylhydrazones as potent antimalarial agents active against CQ-resistant P. falciparum strains. Bioorg. Med. Chem. Lett. 2006, 16, 5384-5388.

30. Bernardino, A.; Gomes, A., Charret, K.; Freitas, A.; Machado, G.; Canto-Cavalheiro, M.; Leon, L.; Amaral, V. Synthesis and leishmanicidal activities of 1-(4-X-phenyl)-N'-[(4-Yphenyl)methylene]-1H-pyrazole-4-carbohydrazides Eur. J. Med. Chem. 2006, 41, 80-87.

31. Küçükgüzel, Ş.G.; Rollas S.; Erdeniz H.; Kiraz M. Synthesis, Characterization and Antimicrobial Evaluation of Ethyl 2-Arylhydrazono-3-oxobutyrates, Eur. J. Med. Chem. 1999, 34, 153-160 .

32. Tavares, L.C.;Chiste, J.J.; Santos, M.G.B.; Penna, T.C.V. Synthesis and biological activity of nifuroxazide and analogs. II . Boll. Chim. Farm. 1999, 138, 432-436.

33. Ulusoy, N.; Çapan, G.; Ötük, G.; Kiraz, M. Synthesis and antimicrobial activity of new 6phenylimidazo[2,1-b]thiazole derivatives. Boll. Chim. Farm. 2000, 139, 167-172.

34. Turan-Zitouni, G.; Blache, Y.; Güven, K. Synthesis and antimicrobial activity of some imidazo[1,2-a]pyridine-2-carboxylic acid arylidenehydrazide derivatives. Boll. Chim. Farm. 2001, 140, 397-400.

35. Vicini, P. ; Zani, F.; Cozzini, P. ; Doytchinova, I. Hydrazones of 1,2-benzisothiazole hydrazides: synthesis, antimicrobial activity and QSAR investigations. Eur. J. Med. Chem. 2002, 37, 553-564.

36. Küçükgüzel , Ş.G.; Mazi, A.; Şahin, F.; Öztürk S.; Stables, J. P. Synthesis and biological activities of diflunisal hydrazide-hydrazones. Eur. J. Med. Chem. 2003, 38, 1005-1009.

37. Loncle, C. ; Brunel, J.; Vidal, N.; Dherbomez, M.; Letourneux, Y. Synthesis and antifungal activity of cholesterol-hydrazone derivatives. Eur. J. Med. Chem. 2004, 39, 1067-1071.

38. Masunari, A.; Tavares, L.C. A new class of nifuroxazide analogues : Synthesis of 5-nitrophene derivatives with antimicrobial activity against multidrug-resistant Staphylococcus aureus. Bioorg. Med. Chem. 2007, 15 , 4229-4236. 
39. www.TAACF.org.

40. Bukowski L.; Janowiec, M. 1-Methyl-1H-2-imidazo[4,5-b]pyridinecarboxylic acid and some of derivatives with suspected antituberculotic activity. Pharmazie 1996, 51, 27-30.

41. Cocco, M.T.; Congiu, C.; Onnis, V.; Pusceddo, M.C.; Schivo, M.L.; De Logu, A. Synthesis and antimycobacterial activity of some isonicotinoylhydrazones. Eur. J. Med. Chem. 1999, 34, 10711076.

42. Bukowski L.; Janowiec, M.; Zwolska-Kwiek, Z.; Andrzejczyk, Z. Synthesis and some reactions of 2- acetylimidazo[4,5-b]pyridine. Antituberculotic activity of the obtained compounds. Pharmazie 1999, 54, 651-654.

43. Mamolo M.G. Falagiani, V.; Zampieri, D.; Vio, L.; Banfi , E. Synthesis and antimycobacterial activity of [5-(pyridin-2-yl)-1,3,4-thiadiazole-2-ylthio]acetic acid arylidene-hydrazide derivatives. Farmaco 2001, 56, 587-592.

44. Ulusoy, N.; Gürsoy, A.; Ötük, G.; Kiraz, M. Synthesis and antimicrobial activity of some 1,2,4triazole-3-mercaptoacetic acid derivatives. Farmaco 2001, 56, 947-952.

45. Savini L.; Chiasserini, L.; Gaeta, A.; Pellerano, C. Synthesis and Anti-tubercular Evaluation of Quinolylhydrazones.Bioorg. Med. Chem. 2002, 10 , 2193-2198.

46. Rando D.; Sato, D.N.; Siqueira, L.; Malvezzi, A.; Leite, C.Q.F.; Amaral, A.T.; Ferreira, E.I.; Tavares, L.C. Potential tuberculostatic agents. Topliss application on benzoic acid [(5-Nitrothiophene-2-yl)methylene] hydrazide series. Bioorg. Med. Chem. 2002, 10 , 557-560.

47. Kaymakçığlu K.B.; Rollas, S. Synthesis, characterization and evaluation of antituberculosis activity of some hydrazones. Farmaco 2002, 57, 595-599.

48. Küçükgüzel, Ş.G.; Rollas, S. Synthesis, Characterization of Novel Coupling Products and 4Arylhydrazono-2-pyrazoline-5-ones as Potential Antimycobacterial Agents. Farmaco 2002, 57, 583-587.

49. Mamolo M.G.; Falagiani, V.; Zampieri, D.; Vio, L.; Banfi , E.; Scialino, G. Synthesis and antimycobacterial activity of (3,4-diaryl-3H-thiazole-2-ylidene)hydrazide derivatives. Farmaco 2003, 58, 631-637.

50. Sriram, D.; Yogeeswari, P.; Madhu, K. Synthesis and in vitro and in vivo antimycobacterial activity of isonicotinoyl hydrazones. Bioorg. Med. Chem. Lett. 2005, 15, 4502-4505.

51. Maccari, R.; Ottana, R.; Vigorita, M.G. In vitro advanced antimycobacterial screening of isoniazid-related hydrazones, hydrazides and cyanoboranes: Part 14. Bioorg. Med. Chem. Lett. 2005, 15, 2509-2513.

52. Shindikar, A.V.; Viswanathan, C.L. Novel fluoroquinolones : design, synthesis, and in vivo activity in mice against Mycobacterium tuberculosis H37 Rv . Bioorg. Med. Chem Lett., 2005 , 15, 1803-1806.

53. Sinha, N.; Jain, S.; Tilekar, A. ; Upadhayaya, R.S.; Kishore, N.; Jana, G.H.; Arora, S.K. Synthesis of isonicotinic acid $\mathrm{N}^{\prime}$-Arylidene-N-[2-oxo-2-(4-aryl-piperazin-1-yl)ethyl]hydrazides as antituberculosis agents. Bioorg. Med. Chem Lett. 2005, 15, 1573-1576.

54. Sriram, D.; Yogeeswari, P.; Madhu, K. Synthesis and in vitro antitubercular activity of some 1-[(4sub)phenyl]-3-(4-\{1-[(pyridine-4-carbonyl)hydrazono]ethyl $\}$ phenyl)thiourea. Bioorg. Med. Chem. 2006, 14, 876-878. 
55. Nayyar, A.; Malde, A.; Coutinho, E.; Jain, R. Synthesis, anti-tuberculosis activity, and 3D-QSAR study of ring-substituted-2/4-quinolinecarbaldehyde derivatives. Bioorg. Med. Chem. 2006, 14, 7302-7310.

56. Sriram, D.; Yogeeswari, P.; Devakaram, R.V. Synthesis, in vitro and in vivo antimycobacterial activities of diclofenac acid hydrazones and amides. Bioorg. Med. Chem. 2006, 14, 3113-3118.

57. Bijev A. New heterocyclic hydrazones in the search for antitubercular agents: Synthesis and in vitro evaluations. Lett.Drug Des. Discov. 2006, 3, 506-512.

58. Shiradkar, M.R.; Murahari, K.K.; Gangadasu, H.R.; Suresh, T.; Kalyan, C.C.; Panchal, D.; Kaur, R.; Burange, P.; Ghogare, J.; Mokale, V.; Raut, M. Synthesis of new S-derivatives of clubbed triazolyl thiazole as anti-Mycobacterium tuberculosis agents. Bioorg. Med. Chem. 2007, 15, 39974008.

59. Imramovský A.; Polanc, S.;Vinšová, J.; Kočevar, M.; Jampílek, J.; Rečková, Z.; Kaustová, J. A new modification of anti-tubercular active molecules. Bioorg. Med. Chem. 2007, 15, 2551-2559.

60. Pandey, J.; Pal, R.; Dwivedi, A.; Hajela, K. Synthesis of some new diaryl and triaryl hydrazone derivatives as possible estrogen receptor modulators. Arzneimittelforschung. 2002, 52, 39-44.

61. Abadi, A.H.; Eissa, A.A.H.; Hassan, G.S. Synthesis of novel 1,3,4-trisubstituted pyrazole derivatives and their evaluation as antitumor and antiangiogenic agents. Chem. Pharm. Bull. 2003, 51, 838-844.

62. Terzioğlu, N.; Gürsoy, A. Synthesis and anticancer evaluation of some new hydrazone derivatives of 2,6-dimethylimidazo[2,1-b]-[1,3,4]thiadiazole-5-carbohydrazide. Eur. J. Med. Chem. 2003, 38, 781-786.

63. Gürsoy, A.; Karali, N. Synthesis and primary cytotoxicity evaluation of 3-[[(3-phenyl-4(3H)quinazolinone-2-yl)mercaptoacetyl]hydrazono]-1H-2-indolinones. Eur. J. Med. Chem. 2003, 38, 633-643.

64. Savini L.; Chiasserini, L.; Travagli, V.; Pellerano, C.; Novellino, E.; Cosentino, S.; Pisano, M.B. New $\alpha$-heterocyclichydrazones : evaluation of anticancer, anti-HIV and antimicrobial activity. Eur.J.Med.Chem. 2004, 39,113-122.

65. Zhang, H.; Drewe, J.; Tseng, B.; Kasibhatla, S.; Cai, S.X. Discovery and SAR of indole-2carboxylic acid benzylidenehydrazides as a new series of potent apoptosis inducers using a cellbased HTS assay. Bioorg. Med. Chem. 2004, 12, 3649-3655.

66. Demirbas N.; Karaoglu S.; Demirbas A.; Sancak K. Synthesis and antimicrobial activities of some new 1-(5-phenylamino-[1,3,4]thiadiazol-2-yl)methyl-5-oxo-[1,2,4]triazole and 1-(4-phenyl-5thioxo-[1,2,4]triazol-3-yl)methyl-5-oxo-[1,2,4]triazole derivatives. Eur. J. Med. Chem. 2004, 39, 793-804.

67. Cocco, M. T.; Congiu, C.; Lilliu,V.; Onnis, V. Synthesis and in vitro antitumoral activity of new hydrazinopyrimidine-5-carbonitrile derivatives. Bioorg. Med. Chem. 2005 , 14, 366-372.

68. Vicini, P.; Incerti, M.; Doytchinova, I.; La Colla, P.; Busonera, B.; Loddo, R. Synthesis and antiproliferative activity of benzo[d]isothiazole hydrazones. Eur. J.Med. Chem. 2006, 41, 624-632.

69. Jin, L.; Chen, J.; Song, B.; Chen, Z.; Yang, S. ; Li, Q.; Hu, D.; Xu R. Synthesis, structure, and bioactivity of $\mathrm{N}^{\prime}$-substitutedbenzylidene-3,4,5-trimethoxybenzohydrazide and 3-acetyl-2- 
substituted phenyl-5-(3,4,5-trimethoxyphenyl)-2,3-dihydro-1,3,4-oxadiazole derivatives. Bioorg. Med. Chem. Lett. 2006, 16, 5036-5040.

70. Gürsoy, E.; Güzeldemirci-Ulusoy, N. Synthesis and primary cytotoxicity evaluation of new imidazo[2,1-b]thiazole derivatives. Eur. J. Med. Chem. 2007, 42, 320-326.

71. El-Hawash, S.A.M.; Abdel Wahab, A.E.; El-Dewellawy, M.A. Cyanoacetic acid hydrazones of 3(and 4-) acetylpyridine and some derived ring systems as potential antitumor and anti-HCV agents. Arch. Pharm. Chem. Life Sci. 2006, 339, 14-23.

72. Silva, A.G.; Zapata-Suto, G.; Kummerle, A.E.; Fraga, C.A.M.; Barreiro, E.J.; Sudo, R.T. Synthesis and vasodilatory activity of new N-acylhydrazone derivatives, designed as LASSBio294 analogues.Bioorg. Med. Chem. 2005, 13, 3431-3437.

73. Abdel-Aal, M.T.; El-Sayed, W.A.; El-Ashry, E.H. Synthesis and antriviral evaluation of some sugar arylglycinoylhydrazones and their oxadiazoline derivatives. Arch. Pharm. Chem. Life Sci. 2006, 339, 656-663.

74. Friedman, J.F.; Mital, P.; Kanzaria, H.K.; Olds, G.R.; Kurtis, J.D. Schistosomiasis and pregnancy. Trends Parasitol. 2007, 23, 159-164.

75. Sulaiman, S.M.; Ali, H.M.; Homeida, M.M.; Bennett, J.L. Efficacy of a new Hoffmann-La Roche compound (RO-15-5458) against Schistosoma mansoni (Gezira strain, Sudan) in vervet monkeys (Cercopithecus aethiops). Trop. Med. Parasitol. 1989, 40, 335-336.

76. Pereira, L.H.; Coelho, P.M.; Costa, J.O.; de Mello, R.T. Activity of 9-acridanone-hydrazone drugs detected at the prepostural phase, in the experimental schistosomiasis mansoni. Mem. Inst. Oswaldo Cruz. 1995, 90, 425-428.

77. Nayyar, A.; Jain, R. Recent advances in new structural classes of anti-tuberculosis agents. Curr. Med. Chem. 2005, 12, 1873-1886.

78. Scior, T.; Garcés-Eisele, S.J. Isoniazid is not a lead compound for its pyridyl ring derivatives, isonicotinoyl amides, hydrazides and hydrazones: A critical review. Curr. Med. Chem. 2006, 13, 2205-2219.

79. Janin, Y. Antituberculosis drugs: Ten years of research. Bioorg. Med. Chem. 2007, 15, 24792513.

Sample Availability: Samples are available from the authors.

(C) 2007 by MDPI (http://www.mdpi.org). Reproduction is permitted for noncommercial purposes. 